\title{
Pengaruh pemberian ekstrak daun cengkeh (Syzygium aromaticum) terhadap gambaran histopatologik hati tikus wistar yang diberikan parasetamol dosis toksik
}

\author{
${ }^{1}$ Denty M. Sidabutar \\ ${ }^{2}$ Carla F. Kairupan \\ ${ }^{2}$ Meilany Durry
}

\author{
${ }^{1}$ Kandidat Skripsi Fakultas Kedokteran Universitas Sam Ratulangi Manado \\ ${ }^{2}$ Bagian Patologi Anatomi Fakultas Kedokteran Universitas Sam Ratulangi Manado \\ Email: dentysidabutar@ymail.com
}

\begin{abstract}
Clove (Syzygium aromaticum) contains eugenol, a phenolic compound, which has been suggested to possess antioxidant activity. This compound is suspected to be able to minimize damage to the liver cells caused by drugs such as paracetamol. This study aimed to observe the effects of clove leaf extract on histopathological features of Wistar rat liver tissue induced with toxic doses of paracetamol. This was an experimental laboratory study. Subjects were 24 male Wistar rats. The dose of clove leaf extract was $200 \mathrm{mg} /$ day (single dose) and of paracetamol 50 $\mathrm{mg}$ /day (single dose) orally. Group A (negative control) was given no treatment for 14 days. Group B was given paracetamol for 14 days. Group C was given clove leaf extract for 7 days and then added with paracetamol for 7 days. Group D was given clove leaf extract and paracetamol simultaneously for 14 days. Group A showed normal histological feature of liver cells. Group B showed liver cell damage induced by paracetamol. Group C showed regeneration of liver cells, but there were still some necrosis and fatty liver cells. Group D showed regeneration of liver cells meanwhile cell necrosis was hardly found. Conclusion: Clove leaf extract could improve the histopathological changes of liver tissues of Wistar rats due to administration of paracetamol at toxic dose. This improvement was manifested as better regeneration of liver cells than that of rats not treated with clover leaf extract.
\end{abstract}

Keywords: clove, paracetamol, liver

\begin{abstract}
Abstrak: Cengkeh (Syzygium aromaticum) mengandung senyawa eugenol, suatu komponen fenolik yang memiliki aktivitas antioksidan. Senyawa eugenol diduga dapat meminimalisir kerusakan sel hati yang antara lain disebabkan oleh obat-obatan yang berefek hepatototoksik seperti parasetamol. Penelitian ini bertujuan untuk mengetahui pengaruh pemberian ekstrak daun cengkeh terhadap gambaran histopatologik hati tikus wistar yang diinduksi dengan parasetamol dosis toksik. Jenis penelitian ini eksperimental laboratorik. Subjek penelitian 24 ekor tikus wistar. Pada penelitian ini digunakan ekstrak daun cengkeh $200 \mathrm{mg} /$ hari (dosis tunggal) dan obat parasetamol $50 \mathrm{mg} / \mathrm{hari}$ (dosis tunggal) per oral. Subjek penelitian dibagi menjadi 4 kelompok. Kelompok A (kontrol negatif) tidak diberi perlakuan selama 14 hari. Kelompok B diberikan parasetamol selama 14 hari. Kelompok C diberikan ekstrak daun cengkeh selama 7 hari kemudian ditambahkan parasetamol secara bersamaan selama 7 hari. Kelompok D diberikan ekstrak daun cengkeh dan parasetamol secara bersamaan selama 14 hari. Kelompok A memperlihatkan gambaran histopatologik sel hati normal. Kelompok B memperlihatkan kerusakan sel hati berupa nekrosis dan perlemakan sel. Kelompok C memperlihatkan regenerasi sel hati namun masih terdapat nekrosis dan perlemakan sel hati. Kelompok D memperlihatkan regenerasi sel hati yang luas dan hampir tidak ditemukan nekrosis sel. Simpulan: Pemberian ekstrak daun cengkeh memperlihatkan perbaikan gambaran histopatologik jaringan hati tikus wistar yang mengalami kerusakan akibat parasetamol dosis toksik berupa regenerasi sel hati yang lebih baik dibandingkan dengan yang terlihat pada jaringan hati tikus wistar yang tidak diberi ekstrak daun cengkeh.
\end{abstract}

Kata kunci: cengkeh, parasetamol, hati 
Cengkeh (Syzigium aromaticum) merupakan salah satu tanaman rempah yang dapat ditemukan di Indonesia dan dimanfaatkan terutama dalam industri rokok, makanan dan obat-obatan. ${ }^{1}$ Daun dan buah cengkeh mengandung komponen fenolik yang tinggi yaitu senyawa eugenol masing-masing $70-80 \%$ dan 50-55\%. Senyawa ini bermanfaat sebagai antioksidan. $^{1,2}$ Kerusakan sel hati dapat disebabkan oleh berbagai faktor, di antaranya ialah penggunaan obat-obatan. Terdapat beberapa jenis obat yang bersifat larut dalam lemak dan tidak mudah diekskresikan sehingga berakibat toksik pada sel hati. Obat yang berpotensi sebagai hepatotoksik antara lain parasetamol, OAT (rifampisin, isoniazid, pirazinamid, ethambutol) dan kortikosteroid. ${ }^{3}$

Penelitian ini bertujuan untuk mengetahui pengaruh pemberian ekstrak daun cengkeh terhadap gambaran histopatologik hati tikus wistar yang diinduksi parasetamol dosis toksik.

\section{METODE PENELITIAN}

Jenis penelitian ini eksperimental laboratorik yang dilakukan pada bulan September 2015 sampai Februari 2016 di Laboratorium Patologi Anatomi Fakultas Kedokteran Universitas Sam Ratulangi Manado. Subjek penelitian ialah 24 ekor tikus Wistar spesies Rattus novergicus jaantan dengan berat rata-rata $200 \mathrm{~g}$. Ekstrak daun cengkeh yang digunakan merupakan ekstrak etanol dengan dosis 200 $\mathrm{mg} /$ tikus/hari (dosis tunggal). ${ }^{4}$ Obat parasetamol yang digunakan ialah tablet $500 \mathrm{mg}$ yang dijual bebas dengan dosis (toksik) $50 \mathrm{mg} /$ tikus/hari (dosis tunggal). ${ }^{5}$ Ekstrak daun cengkeh dan parasetamol dilarutkan menggunakan $1 \mathrm{ml}$ aquades lalu diberikan secara oral menggunakan sonde lambung khusus untuk tikus.

Subjek penelitian dibagi dalam 4 kelompok, yaitu satu kelompok kontrol negatif dan tiga kelompok perlakuan. Kelompok A (kontrol negatif) tidak diberikan perlakuan selama 14 hari. Kelompok B diberikan parasetamol 50 $\mathrm{mg} / \mathrm{hari}$ dosis tunggal selama 14 hari.
Kelompok C diberikan ekstrak daun cengkeh $200 \mathrm{mg} / \mathrm{hari}$ dosis tunggal selama 7 hari dilanjutkan dengan pemberian parasetamol $50 \mathrm{mg} /$ hari dosis tunggal dan ekstrak daun cengkeh secara bersamaan selama 7 hari. Kelompok D diberikan ekstrak daun cengkeh $200 \mathrm{mg} / \mathrm{hari}$ dosis tunggal dan parasetamol $50 \mathrm{mg} /$ hari dosis tunggal secara bersamaan selama 14 hari. Terminasi hewan uji dilakukan pada hari ke-15 untuk mengambil organ hati. Organ hati diproses untuk pembuatan preparat histopatologik dan diamati dengan mikroskop cahaya.

\section{HASIL PENELITIAN \\ Kelompok A (kontrol negatif)}

Gambaran mikroskopik hati tikus wistar pada kelompok ini menunjukkan struktur dari sel-sel normal. Tampak letak dan susunan segitiga Kiernan, vena sentralis dan hepatosit yang normal. Tidak ditemukan adanya kelainan (Gambar 1).
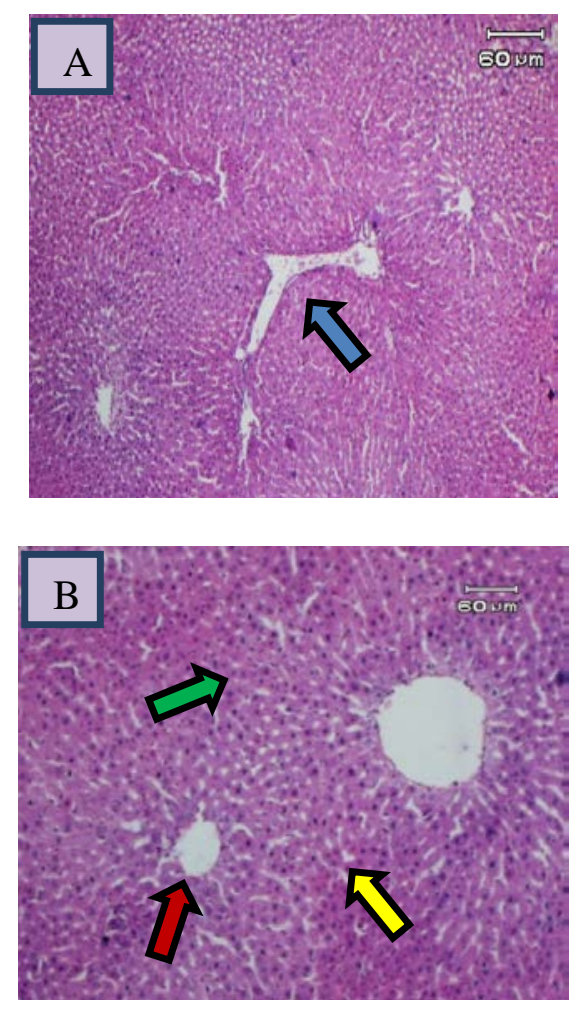

Gambar 1. Gambaran mikroskopik hati tikus wistar kelompok A (kontrol negatif). Tampak gambaran hati normal dengan vena sentralis (panah merah), hepatosit (panah hijau), sinusoid (panah kuning) dan segitiga Kiernan (panah biru). A: pembesaran 40x dan B: pembesaran 100x. 


\section{Kelompok B}

Kelompok B adalah kelompok tikus wistar yang diberi perlakuan parasetamol dosis toksik selama 14 hari. Pada kelompok ini tampak adanya perlemakan dan nekrosis sel hati. Tampak pula sel-sel eritrosit di sinusoid (Gambar 2).
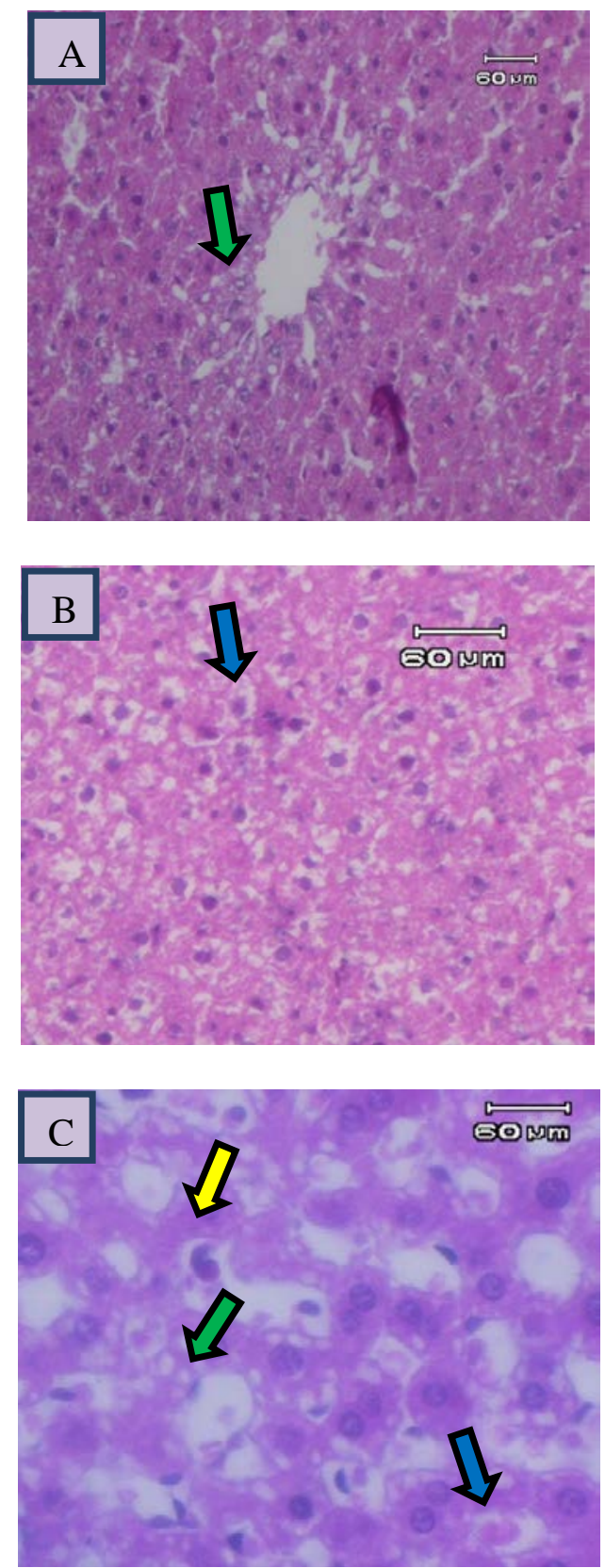

Gambar 2. Gambaran mikroskopik hati tikus kelompok B (perlakuan 1). Tampak gambaran hati tidak normal dengan adanya perlemakan hati (panah hijau), sinusoid berisi eritrosit (panah biru) dan nekrosis sel (panah kuning). A: pembesaran 40x, B dan C: pembesaran 100x.

\section{Kelompok C}

Kelompok C ialah kelompok tikus wistar yang diberi ekstrak daun cengkeh saja selama 7 hari dilanjutkan dengan pemberian parasetamol dosis toksik dan ekstrak daun cengkeh. Pada kelompok ini tampak adanya regenerasi sel hati dimana sel-sel tidak beraturan, memiliki inti besar, dan sitoplasma eosinofilik; juga masih terdapat nekrosis dan perlemakan sel hati (Gambar 3).
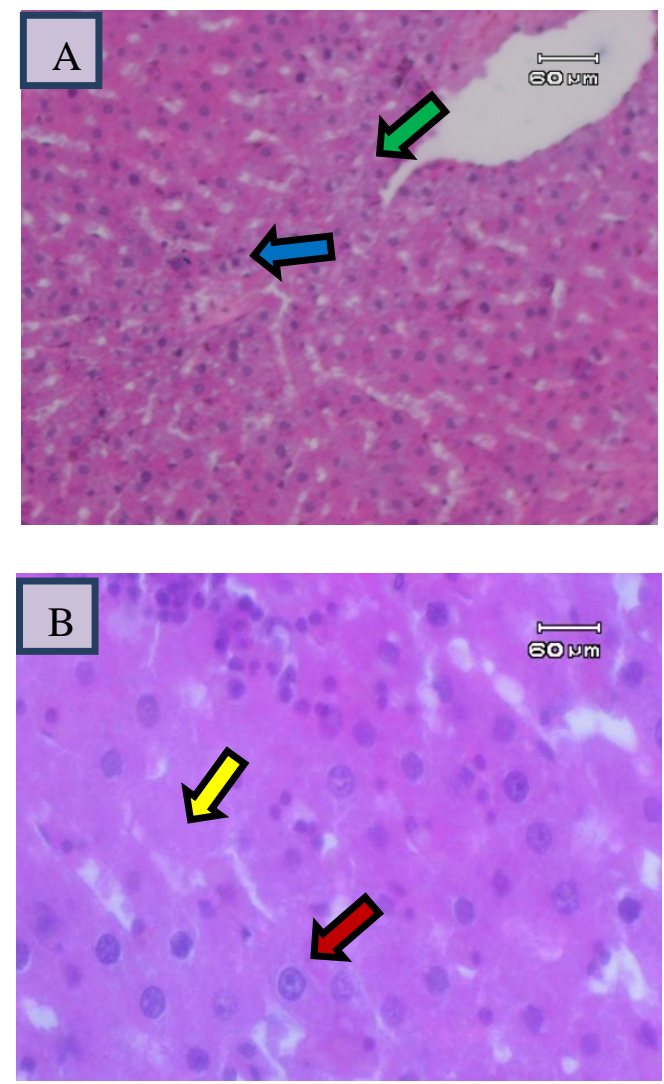

Gambar 3. Gambaran mikroskopik hati tikus kelompok C (perlakuan 2). Tampak gambaran sel hati yang mengalami regenerasi (panah biru) dengan inti sel yang besar (panah merah), masih ada perlemakan (panah hijau) dan nekrosis sel hati (panah kuning). A: pembesaran 40x, B dan C: pembesaran 100x.

\section{Kelompok D}

Kelompok D adalah kelompok tikus wistar yang diberi parasetamol dosis toksik dan ekstrak daun cengkeh selama 14 hari. Pada kelompok ini tampak adanya regenerasi sel hati yang luas dan sel-sel tersusun beraturan. Nekrosis sel hampir tidak terlihat (Gambar 4). 

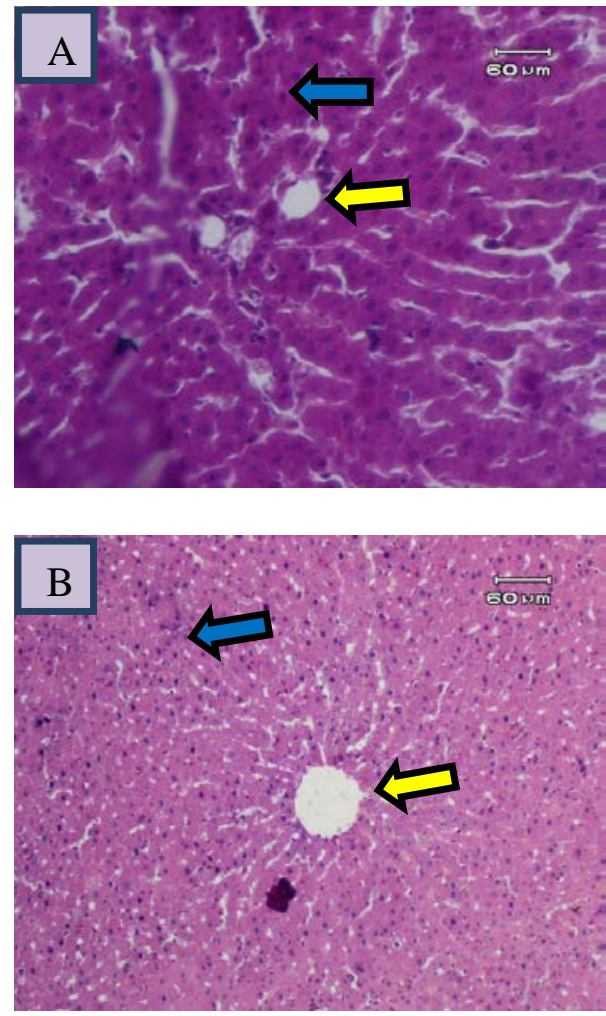

Gambar 4. Gambaran mikroskopik hati tikus kelompok D (perlakuan 3). Tampak gambaran sel hati yang mengalami regenerasi pada hampir seluruh bagian jaringan (panah biru), hampir tidak ditemukan nekrosis pada sel dan tampak vena sentralis (panah kuning). A: pembesaran 40x dan B pembesaran 100x.

\section{BAHASAN}

Kerusakan sel hati dapat disebabkan oleh berbagai faktor, di antaranya ialah penggunaan beberapa obat secara terusmenerus dan tidak sesuai dengan dosis yang dianjurkan. Parasetamol merupakan salah satu zat toksik yang dapat menyebabkan kerusakan sel hati. ${ }^{3}$ Penelitian ini memberikan informasi mengenai gambaran histopatologik hati tikus wistar yang diberikan parasetamol dosis toksik dan ekstrak daun cengkeh dengan membandingkan kelompok kontrol negatif dan kelompok perlakuan.

Hasil penelitian ini menunjukkan perbedaan gambaran mikroskopik antara hati tikus wistar kelompok kontrol negatif dengan kelompok perlakuan. Pada kelompok A tampak gambaran sel hati normal sedangkan pada kelompok B tampak kerusakan sel hati akibat parasetamol dosis toksik. Penggunaan parasetamol dosis tinggi akan menyebabkan akumulasi N-acetyl-pbenzoquinoneimine (NAPQI) yaitu metabolit yang sangat reaktif dan menyebabkan cedera sel hati yang mengarah ke nekrosis sentrilobulus dan selanjutnya gagal hati. Cedera sel hati yang diakibatkan oleh akumulasi NAPQI melibatkan 2 mekanisme yaitu (1) ikatan kovalen pada protein hati menyebabkan kerusakan membran sel dan disfungsi mitokondria, dan (2) penyusutan GSH mengakibatkan hepatosit lebih rentan terhadap kerusakan akibat radikal bebas. ${ }^{6}$

Kelompok tikus wistar yang diberi ekstrak daun cengkeh selama 7 hari dilanjutkan dengan pemberian parasetamol dosis toksik dan ekstrak daun cengkeh secara bersamaan selama 7 hari (kelompok C) menunjukkan adanya regenerasi sel, namun masih terdapat nekrosis sel di beberapa area kecil. Sedikit berbeda dengan kelompok $\mathrm{C}$, hati dari tikus pada kelompok yang diberikan ekstrak daun cengkeh bersamaan dengan parasetamol dosis toksik selama 14 hari (kelompok D) menunjukkan regenerasi sel dan hepatosit yang sudah mulai teratur dan tampak seperti sel-sel normal. Tanda regenerasi/ perbaikan sel-sel hati pada kelompok D ini tampak lebih banyak/baik dibandingkan dengan yang terlihat pada kelompok C. Perlemakan dan nekrosis sel juga hampir tidak terlihat pada kelompok D. Efek anti inflamasi dari eugenol dalam ekstrak daun cengkeh dapat mencegah kerusakan jaringan lebih lanjut akibat efek toksik parasetamol dan khasiatnya sebagai antioksidan dalam proses peroksidasi lipid dapat menghambat perlemakan hati. Eugenol dalam ekstrak daun cengkeh juga mampu menstabilkan radikal bebas dengan mendonorkan elektron atau atom hidrogen sehingga senyawa radikal berubah menjadi lebih stabil. ${ }^{2,7,8}$ Hal ini sesuai dengan penelitian A Mu'nisa et al. $^{2}$ tentang aktivitas antioksidan dan antihiperkolesterolemia ekstrak daun cengkeh pada kelinci.

Gambaran histopatologik yang berbeda 
antar kelompok hewan uji pada penelitian ini menunjukkan adanya pengaruh pemberian ekstrak daun cengkeh dalam mencegah kerusakan sel-sel hati akibat efek toksik parasetamol serta menunjang terjadinya regenerasi sel-sel hati. Keterbatasan dari penelitian ini ialah kurangnya bahasan mengenai farmakokinetik dan farmakodinamik ekstrak daun cengkeh karena referensi yang terkait masih terbatas. Namun demikian, hasil penelitian ini dapat menambah informasi dan pengetahuan mengenai efek positif ekstrak daun cengkeh terhadap kesehatan terutama kesehatan organ hati dan mengembangkan penelitian-penelitian yang berhubungan dengan tanaman cengkeh.

\section{SIMPULAN}

Berdasarkan hasil penelitian ini dapat disimpulkan bahwa ekstrak daun cengkeh mampu memperlihatkan perbaikan yang jelas pada gambaran histopatologik sel hati tikus wistar yang mengalami kerusakan akibat pemberian parasetamol dosis toksik dibandingkan dengan hati tikus wistar yang tidak diberikan ekstrak daun cengkeh, yaitu berupa adanya regenerasi sel hati yang lebih baik.

\section{SARAN}

1. Perlu penambahan jangka waktu perlakuan dan variasi dosis ekstrak daun cengkeh.

2. Perlu dilakukan perhitungan secara kuantitatif jumlah sel regenerasi dan perlemakan sel hati

\section{DAFTAR PUSTAKA}

1. Milind P, Deepa K. Clove: A Champion
Spice. International Journal of Research in Ayurveda \& Pharmacy. 2011;1:h.47-54.

2. Mu'nisa A, Wresdiyati T, Kusumorini N, Manalu W. Aktivitas Antioksidan Ekstrak Daun Cengkeh. Jurnal Veteriner. 2012;13:272.

3. Julita I. Aspek farmakokinetik klinik beberapa obat berpotensi hepatotoksik pada pasien rawat inap di bangsal paru RSUP Dr. Djamil Padang periode Oktober 2011-Januari 2012. Padang: Pasca Unand. 2012.

4. Anas Y, Puspitasari N, Nuria MC. Aktivitas Stimulansia Ekstrak Etanol dan Daun Cengkeh Pada Mencit Jantan Galur Swiss Beserta Identifikasi Golongan Senyawa Aktifnya. Publikasi Ilmiah. 2013;10:13

5. Gunawan SG, Nafrialdi RS, Elysabeth. Analgesik-Antipiretik, Analgesik Anti-Inflamasi Nonsteroid dan Obat Gangguan Sendi Lainnya. Dalam: Tanu I. Farmakologi dan Terapi (5th ed). Jakarta: Departemen Farmakologi dan Terapeutik FKUI, 2007; p.237-9.

6. Perkins AJ. Enviromental and Nutritional Diseases. In: Kumar V, Abbas A, Aster J. Robbins and Cotran Pathologic Basis of Diseases (9th ed). Kanada: Elsevier Saunders, 2015; p. 422.

7. Rorong JA. Uji Aktivitas Antioksidan Dari Daun Cengkeh (Eugenia carryophyllus) Dengan Metode DPPH. Chemistry Progress. 2008;1:111.

8. Tohawa J. Manfaat Eugenol Cengkeh pada Berbagai Industri di Indonesia. Balai Penelitian Tanaman Industri dan Penyegar. Perspektif. 2012;11:92. 